University of Nebraska - Lincoln

DigitalCommons@University of Nebraska - Lincoln

May 1991

\title{
Class Conflict, Corporate Power, and Macroeconomic Policy: The Impact of Inflation in the Postwar Period
}

\author{
Ann Mari May \\ University of Nebraska - Lincoln, amay1@UNL.edu \\ Randy R. Grant \\ University of Nebraska - Lincoln
}

Follow this and additional works at: https://digitalcommons.unl.edu/cbafacpub

Part of the Business Commons

May, Ann Mari and Grant, Randy R., "Class Conflict, Corporate Power, and Macroeconomic Policy: The Impact of Inflation in the Postwar Period" (1991). College of Business Faculty Publications. 22.

https://digitalcommons.unl.edu/cbafacpub/22

This Article is brought to you for free and open access by the Business, College of at DigitalCommons@University of Nebraska - Lincoln. It has been accepted for inclusion in College of Business Faculty Publications by an authorized administrator of DigitalCommons@University of Nebraska - Lincoln. 
Published in Journal of Economic Issues 25:2 (June 1991), pp. 373-381.

Copyright (C) 1991 Association for Evolutionary Economics. Used by permission. 


\title{
Class Conflict, Corporate Power, and Macroeconomic Policy: The Impact of Inflation in the Postwar Period
}

\author{
Ann Mari May \\ and \\ Randy R. Grant
}

When Richard Nixon ran for the presidency in 1968, he declared that inflation was America's number one problem. While opinion polls showed otherwise, an undaunted Nixon set about to reduce inflation and to convince the public of the dangers of rising prices. To help in this effort, the Council of Economic Advisors initiated a study to identify those impacted adversely by inflation. The study, however, was disappointing. According to Herbert Stein, "If anyone was being severely hurt, the available statistics were too crude to reveal it."'

Nixon was not the first, nor was he the last president to warn of the hazards of inflation. Virtually every postwar president since Dwight Eisenhower has warned of the ravages of inflation and perpetuated the, by now, unquestioned belief that inflation exacts a tremendous toll on the standard of living of most, if not all Americans. This belief has in turn allowed policymakers to enact contractionary policies that often impose tremendous human costs on those least able to sustain them in an effort to reduce inflation.

The authors are Assistant Professor and graduate student, respectively, in the Department of Economics. L'niversity of Nebraska-Lincoln. This article was presented at the annual mectings of the Association for Evolutionary Economics, 28 December 1990. Washington. D.C. 
While the costs of unemployment are highly visible and identifiable, impacting lower income groups much more significantly than upper income groups, the costs of moderate inflation are more ambiguous. ${ }^{2}$ Like unemployment, the costs of inflation are not shared equally throughout society. However, unlike unemployment, moderate infiation appears to disadvantage the rich and benefit, or at least not hurt, a large proportion of the population.

This article examines inflation in the postwar period and offers an explanation for the aversion to inflation that fits within a radical institutionalist framework. ${ }^{3}$ We suggest that the concern over inflation reflects the interests of corporate welfare over the interests of community welfare. Moreover, anti-inflation efforts have accommodated corporate consolidation and hegemony.

\section{Reexamining the Costs of Inflation}

When the Full Employment Bill was initially proposed in 1945, public support for federal government intervention to maintain full employment was substantial. The Great Depression made the need for government action on the federal level appear obvious, while the success of the war economy of World War II made planning appear possible. However, opposition to the Full Employment Bill quickly mobilized. Not surprisingly, the National Association of Manufacturers and other business organizations argued that the bill would undermine business confidence and lead to inflation. ${ }^{4}$

That government intervention to maintain full employment would undermine business confidence was not an unexpected argument. But the argument that government efforts to maintain full employment would lead to inflation is unique to the postwar period and resulted in the inclusion of price stability as a policy goal in the Employment Act of 1946.

The inclusion of price stability as a policy goal in the Employment Act of 1946 laid the foundation for the postwar debate over macroeconomic policy. Implicit in the policy debate was the assumption that while unemployment impacts different groups differently, inflation hurts all or most Americans. Empirical studies analyzing the costs of inflation, however, do not confirm this assumption.

In a study examining the distribution of money income by quintiles, Alan S. Blinder and Howard Esaki find that inflation has not significantly influenced the size distribution of family income. Their findings indicate that no income groups suffered a significant decline in money 
income from inflation. ${ }^{3}$ Moreover, Robinson Hollister and John Palmer, who examine expenditures, real income, and wealth effects from inflation on the poor and non-poor, find that the relative position of the poor may actually have improved with inflation from 1947 to 1967. In a similar analysis examining expenditures of the poor from 1967 to 1981 , Douglas A. Hibbs Jr. concludes that inflation "may actually have improved somewhat the relative real income position of low-income households."

Finally, Joseph Minarik simulates the effect of moderate inflation on a broader measure of household income called "accrued comprehensive income," which includes consumption plus the change in net worth. Minarik's results show no income loss for low-income households, while middle-income households are unaffected for the most part. In contrast, upper-income households lose substantially from in-. flation. According to Minarik, "greater real income taxes, lagging corporate retained earnings, and especially the depreciation of the face value of dollar-denominated interest-bearing securities combine to make upper income households the big losers from inflation."

The results of these empirical studies would seem to indicate that moderate inflation adversely impacts only upper-income households and may even result in a decrease in income inequality. But what about the corporate sector and corporate income?

Douglas Hibbs examines both pre-tax and after-tax profit shares rates of return from 1950 to 1981 . Hibbs finds that while "inflation bears essentially no connection to either the pretax profit share or the pretax rate of return in the private corporate sector," inflation does adversely impact after-tax profits and the after-tax rate of return. ${ }^{9}$ Depreciation allowances and inventory valuation methods explain this decline in after-tax corporate profits. According to Hibbs, corporate tax law, until 1981, stipulated that depreciation allowances be based upon capital assets valued at historical cost. With inflation, the value of the depreciation allowance is eroded. Additionally, inventory valuation methods such as first in/first out (FIFO) overstate corporate profits and increase corporate taxes by evaluating costs at the oldest levels.

Examination of the empirical evidence suggests that a majority of households do not suffer real income loss as a result of moderate inflation. Far from being a widespread problem affecting all or most Americans, inflation appears to adversely impact only upper-income households, in addition to eroding away after-tax profits. If moderate inflation has such a benign impact, how do we explain the persistent aversion to inflation? 
One possible explanation, offered by Edward Foster, suggests that the public "misunderstands" inflation and attributes declines in real income from other sources, to the effects of inflation. ${ }^{10} \mathrm{~A}$ second explanation offered by Foster is that infiation erodes confidence in government and its ability to solve problems in a just and equitable manner." This argument is, of course, a variant of the one proposed by John Maynard Keynes and more recently by James K. Galbraith. ${ }^{12}$ These arguments, while plausible, do not offer a very satisfying explanation. Keynes and Galbraith's observations would seem to apply more to European countries with historical experience with hyperinflation. Moreover, merely to assume that a majority of the public might believe that their interests are being served by reducing inflation really begs the question.

We suggest that the concern for inflation refiects the imperatives of a corporate capitalist culture and that the consolidation of business creates both inflationary pressure and the imperative to hold those inflationary pressures in check. Moreover, anti-inflation efforts have accommodated corporate consolidation and extended corporate hegemony. Why do Americans believe that even moderate inflation is harmful? Because, as Paul Peretz has argued, they have been told that it is harmful by policymakers, economists, and business leaders who largely refiect the interests of the corporate sector. ${ }^{13}$

\section{A Radical Institutionalist Perspective}

While it is perhaps true that the Marxists have contributed most to our understanding of the relationship between the state and the corporation, institutionalists have become increasingly interested in examining the various aspects of corporate hegemony. ${ }^{14}$ While Gardiner Means and others describe how corporate consolidation contributes to inflation, insufficient attention has been paid to the ways in which macroeconomic policy goals and stabilization policy in the postwar period have reflected the imperatives of a corporate culture.

While empirical studies such as those of Hibbs indicate that infiation has tended to erode away after-tax profits, the factors identified as being most responsible for this decline in profits have changed significantly since 1981. Tax laws concerning depreciation allowances have been changed to allow valuation of capital assets at current levels and many firms have now switched to inventory valuation methods based upon last in/first out (LIFO), thus decreasing corporate tax liability. ${ }^{15}$ Yet, corporate aversion to inflation appears unaltered. 
John Kenneth Galbraith, in The New Industrial State, offers an alternative explanation for the corporate aversion to inflation. In his view, inflation interferes with the planning sector, which requires stability in costs and prices for effective planning. As Galbraith sees it, "Inflationary price and cost increases, moving unpredictably through the system ... introduce an unwelcome element of randomness and error." 16 The uncertainty associated with inflation undermines the corporation's ability to safely engage in long-term contracts. While the planning sector may have market power to pass along cost increases, changes in prices may also make the management of demand more difficult by making consumers more sensitive to changes in prices.

While the goal of reducing inflation appears to reflect the interest of the corporate sector, government policies to reduce inflation have, moreover, accommodated the corporate sector and expanded corporate hegemony by increasing unemployment, weakening labor, and accelerating consolidation and concentration. Throughout the postwar period, policy-makers have consistently fought inflation through contractionary aggregate demand policies and consistently denied that it would increase unemployment. From Richard Nixon's "gradualism" to Ronald Reagan's "supply-side" machinations, we have been promised a painless solution to inflation and given a good dose of unemployment and recession. In what ways have these induced recessions advanced the interests of the corporate sector? Given that corporate profits are highly pro-cyclical, isn't it in the interest of the corporate sector to guarantee sustained expansion?

This is not, of course, a new question. Michal Kalecki, in 1943, addressed this question and argued that capitalist systems will continue to experience periodic unemployment, not because governments would be technically incapable of maintaining full employment, but because the government would intentionally create recession and unemployment. Kalecki shared Marx's view that the state is an arm of the capitalist class and argued that politicians would respond to pressure from groups averse to maintaining full employment, those who require periodic unemployment or the threat of unemployment to "discipline in the factories." 17 Therefore, while periodic unemployment and recession reduce corporate profits, they also provide a valuable means of controlling labor. However, our increasing reliance on monetary policy as a means of fighting inflation also serves the interest of the corporate sector.

Reflecting upon The New Industrial State, Galbraith suggests that the planning system's control over the state has gone beyond what Gal- 
braith had himself envisioned some twenty years earlier. Moreover, Galbraith did not anticipate the "escape into monetarism" with its high real interest rates and the degree to which monetary policy would accommodate the needs of the planning sector. "Like others," Galbraith remarked, "while doubting the efficacy of monetary policy, I assumed it to be socially and politically neutral. It assuredly is not."18

Monetary policy has increasingly been the preferred, although not sole, policy tool for fighting inflation. When inflation began to increase in the mid-1960s, it was contractionary monetary policy that was first to respond. The result was the 1966 credit crunch. In 1973 when the Organization of Petroleum Exporting Countries (OPEC) quadrupled the price of oil, it was the Federal Reserve's offsetting response of contractionary policies that helped propel the economy into the worst recession, at that time, since the Great Depression. Again in 1980, monetary policy turned wildly contractionary in response to another supply-side shock. Moreover, the 1981-1982 recession, now the worst since the Great Depression, was also largely the result of severely contractionary monetary policy.

Many reasons account for the use of contractionary monetary policy to fight inflation. The growth of entitlement programs, defense spending, and the increase in the interest component of government outlays have made a large portion of the budget untouchable. These factors, along with the reluctance of politicians to raise taxes, may also account for the use of monetary policy. But there are other compelling factors that suggest why monetary policy has been the weapon of choice in fighting inflation.

As Galbraith has suggested, contractionary monetary policy results in high real interest rates, which have been attractive to upper income individuals and large corporations. Because nonfinancial corporations are less dependent upon external sources to finance capital expenditures, they, along with individuals with money to lend, benefit from high real interest rates. ${ }^{19}$ Both wealthy individuals and corporations benefit from high real interest rates on financial assets without suffering losses from borrowing in credit markets. Perhaps more important, however, is the impact of high real interest rates on corporate concentration and power.

In their study of credit markets, E. W. Davis and K. A. Yeomans assert that restrictive monetary policy allows larger companies to put a "credit squeeze" on their smaller competitors. Examining liquidity and net trade credit given during the "ease" and "squeeze" periods, $\mathrm{Da}$ vis and Yeomans conclude that small companies suffer liquidity dete- 
rioration and increase their bank borrowing during the squeeze years. Because small firms lack the corporation's ability to finance internally, they are far more vulnerable to problems of insufficient credit. The primary significance of the squeeze on small companies is that the weakened position of smaller firms increases the likelihood of concentration in that industry. ${ }^{20}$

Increasing concentration does more than enhance corporate power; it also tends to increase income inequality. In an empirical study analyzing the relationship between concentration and income distribution, Irene Powell finds that a reduction in concentration results in a decrease in income inequality. ${ }^{21}$ When concentration decreases, excess profits decline, resulting in falling prices for consumers. Powell argues that these falling prices benefit lower-income households while reducing income to upper-income households. She concludes that a reduction in concentration is associated with a decrease in income inequality. Although Powell's study examines the impact of decreases in concentration on income inequality, the opposite case can easily be made that increases in industry concentration would result in an increase in income inequality.

The use of contractionary monetary policy increases income inequality indirectly through its impact on industry concentration and directly through high interest rates in general. Since the majority of interest-bearing assets are held by wealthier individuals, increases in real interest rates will raise their relative income. In part because of higher real interest rates, the interest component of national income has risen to around ten percent. ${ }^{22}$

\section{Concluding Remarks}

In Radical Institutionalism: Contemporary Voices, James Dietz critically evaluates the contribution that radical institutionalists might make to our understanding of political economy. Dietz argues that a useful avenue for exploration concerns the role of the state in a culture of corporate capitalism. Moreover, examination of the role of the state will most likely entail a class rather than class-less interpretation, where "changes that truly benefit classes other than the ruling class" are possible while the "thrust of the state's efforts must, and will, be directed toward providing an environment in which the capitalist productive apparatus is effectively reproduced."23

Because evidence suggests that inflation hurts upper-income households and the corporate sector while, if not benefiting, at least not hurt- 
ing a majority of the population, the aversion to infiation and the policy induced contractions to fight inflation are best viewed within the framework of class. As Harry G. Johnson has said, "From one important point of view, indeed, the avoidance of inflation and the maintenance of full employment can be most usefully regarded as conflicting class interests. $" 24$

The tension generated by the class struggle over the inflationunemployment trade-off has been mediated, in part, by the state. The state, as Marx and Veblen believed, has often, although not always, accommodated the interests of the corporate class where the corporate class is not merely profit-maximizing, but seeks power as well as profits. In addition, the state often attempts to mold public opinion to conform to the interests of the corporate class.

The state's role in shaping public opinion on the costs of inflation represents an example of what William Dugger has referred to as an "enabling myth."2s The belief that inflation is detrimental to everyone not only allows politicians to pursue anti-inflationary policies that benefit the interests of the corporate class, but compels them to do so. In so doing, the inflation myth perpetuates economic and social policies that enhance the power and status of corporations, exacerbate income inequality, and undermine participatory democracy.

\section{Notes}

1. Herbert Stein, Presidential Economics: The Making of Economic Policy from Roosevelt to Reagan and Beyond (New York: Simon and Schuster, 1984), p. 149.

2. This article examines only the impact of moderate inflation which, as a benchmark estimate, we consider to be at or below 10 percent.

3. See William M. Dugger, ed. Radical Institutionalism: Contemporary Voices (New York: Greenwood Press, 1989).

4. See Stephen K. Bailey, Congress Makes a Law (New York: Columbia University Press. 1950), p. 9 and pp. 130-31.

5. Alan S. Blinder and Howard Y. Esaki, "Macroeconomic Activity and Income Distribution in the Postwar United States," The Review of Economics and Statistics 60 (November 1978), p. 607.

6. Robinson G. Hollister and John L. Palmer, "The Impact of Inflation on the Poor, "in Redistribution to the Rich and the Poor, ed. Kenneth Boulding and Martin Pfaff, (Belmont, Calif: Wadsworth, 1972): 240-70.

7. Douglas A. Hibbs, Jr., American Political Economy: Macroeconomics and Electoral Politics (Cambridge: Harvard University Press, 1987), p. 87.

8. Joseph Minarik, "Who Wins, Who Loses from Inflation?" The Brookings Bulletin 15 (Summer 1978), p. 8.

9. Hibbs, American Political Economy, pp. 100-105. 
10. Edward Foster, "Who Loses From Inflation," Annals of the American Acadcm! of Political and Social Science 456 (July 1981), p. 44.

11. Ibid.. p. 44.

12. James K. Galbraith, "Using the Presidency to Fight Inflation," Challenge (March-April 1985): 19-26.

13. Paul Peretz. The Political Economy of Inflation in the United States (Chicago: University of Chicago, 1983), p. 93.

14. For example, see William M. Dugger, Corporate Hegemony (New York: Greenwood Press, 1989).

15. Hibbs. American Political Economy, p. 101 and p. 104.

16. John Kenneth Galbraith, The New Industrial State (New York: New American Library, 1978), p. 230.

17. Michal Kalecki, "The Political Aspects of Full Employment," Political Quarterly (October/December 1943), p. 326.

18. John Kenneth Galbraith, "The New Industrial State After Twenty Years," American Economic Review 78 (May 1988), p. 375.

19. Frederick H. Jensen, "Recent Developments in Corporate Finance," Fedcral Reserve Bulletin (November 1986), p. 746.

20. E. W. Davis and K. A. Yeomans, Company Finance and the Market (New York: Cambridge University Press, 1974), p. 70 and p. 86.

21. Irene Powell. "The Effect of Reductions in Concentration on Income Distribution," The Review of Economics and Statistics 69 (February 1987): 75-82.

22. Kenneth Boulding, "Puzzles Over Distribution," Challenge (NovemberDecember 1985), p. 10.

23. James Dietz, "Radicals and Institutionalists: Holes, Wholes, and Future Directions," in Dugger, Radical Institutionalism, p. 60.

24. Harry G. Johnson quoted in Hibbs, American Political Economy, p. 1.

25. William M. Dugger, "Instituted Process and Enabling Myth: The Two Faces of the Market," Journal of Economic Issues 23 (June 1989): 607-15. 